\title{
Occurrence of ingression of Salmonella spp. in Betel leaf (Piper betle L.)
}

\author{
Md. Fakruddin ${ }^{*}$, Razia Sultana ${ }^{2}$, Md. Nur Hossain ${ }^{1}$, Md. Mizanur Rahaman', Md. Kamrul Islam² \\ and Monzur Morshed Ahmed ${ }^{1}$
}

\begin{abstract}
Background: Salmonella spp. is one of the most common pathogens associated with fresh produce related foodborne illness. This study aimed to determine Salmonella spp. contamination level in betel leaf, internalization potential and possible decontamination process.

Results: A total of $77 \%$ betel leaf sample collected from local market was found to be contaminated with Salmonella spp. Of all the Salmonella spp. isolated and identified, 28.5\% belong to Salmonella enterica subsp. enterica serovar Enteritidis, 19.5\% belong to Salmonella Typhimurium, 15.6\% to Salmonella Paratyphi, 10.4\% to Salmonella Schottmuelleri, $9.1 \%$ to Salmonella Gallinarum, 10.4\% to Salmonella Choleraesuis and 6.5\% belong to Salmonella Bongori. Internalized Salmonella spp. showed moderate resistance to commonly used antibiotics. Treatment with common surface food disinfectants could not remove Salmonella spp. completely from betel leaf indicating the possibility that the bacteria may be in internal tissue of the leaf. Assessment of internalization potential showed that Salmonella spp. isolated from inner part of betel leaf pose better internalization potential (6.7-7.4 logCFU/gm) comparing with ATCC (American Type Culture Collection) strains (0.86-0.6 logCFU/gm). The isolates also showed better survivability in internalized condition, biofilm formation ability and motility than ATCC strains. Prevalence and expression of invasion (sefA and invA) and type 3 secretion system (TTSS) associated genes (hila, avrA and sopE) were high in internalized Salmonella isolates. Commercial disinfectants as well as $\mathrm{H}_{2} \mathrm{O}_{2}$ were found to have poor efficacy (log reduction around 2 CFU/gm) against internalized Salmonella. Ozonated water showed better decontamination efficiency (log reduction around 3 CFU/gm) whereas ethanolic extract of Terminalia arjuna stem bark showed higher decontamination (log reduction around 4.5 CFU/gm) of internalized Salmonella.
\end{abstract}

Conclusion: Salmonella spp. can ingress into betel leaf and better decontamination treatment is needed to be established. Keywords: Internalization, Salmonella, Betel leaf, Disinfection

\section{Background}

Foodborne illnesses with linkage to consumption of contaminated fresh products (such as betel leaf) is increasing and becoming a significant food safety issue worldwide nowadays (Gomes et al. 2009; Gorny 2006). Contamination can occur at any stage of production such as pre-harvest or post-harvest (Semenov et al. 2010; Goldberg et al. 2011; Bernstein 2011). Some recent studies reported internalization of bacteria into the plant

\footnotetext{
* Correspondence: fakruddinmurad@gmail.com

${ }^{1}$ Industrial Microbiology Laboratory, Institute of Food Science and Technology (IFST), Bangladesh Council of Scientific and Industrial Research (BCSIR), Dr. Kudrat I Khuda Road, Dhanmondi, Dhaka 1205, Bangladesh Full list of author information is available at the end of the article
}

part and subsequent translocation of bacteria to leaf and other aerial parts of the plant (Goldberg et al. 2011; Zhuang et al. 1995; Avila-Quezada et al. 2010; Hirneisen et al. 2012; Zheng et al. 2013; Bernstein et al. 2007a; Bernstein et al. 2007b). This event is alarming due to the fact that internalization of pathogenic bacteria into fresh produce pose high risk to the consumers as they are significantly resistant to external biocidal washing agents (Ibarra-Sanchez et al. 2004; Jablasone et al. 2005; Donkor et al. 2010). Though the mechanism of internalization of bacteria into plant parts are still poorly understood (Auty et al. 2005), both plant and bacteria related factors contribute to its internalization (Erickson et al. 2010; Gu et al. 2011). 
Salmonella spp. is one of the most common pathogens associated with fresh produce related foodborne illness (Sivapalasingam et al. 2004; Lapidot et al. 2006). Recent reports clearly demonstrate that Salmonella not only survive passively, but also infect plants actively (Wiedemann et al., 2015; Schikora et al. 2012; Akhtyamova, 2013). Moreover, infection of plants depends on the active suppression of the host immune responses by Salmonella (Schikora et al. 2012). Most studies on Salmonella plant interactions suggested an epiphytic lifestyle of Salmonella on plants (Berger et al. 2010).

Betel leaf (Piper betle L.) is a masticatory with important socio-cultural and ceremonial use in south and southeast Asia. It is also an economically important export commodity. Betel leaf is consumed raw through chewing mainly by South-Asian populations living worldwide. Betel leaf pose significant nutritional values and medicinal properties and is traditionally known to be useful for the treatment of various diseases like bad breath, boils and abscesses, conjunctivitis, constipation, headache, hysteria, itches, mastitis, mastoiditis, leucorrhoea, otorrhoea, ringworm, swelling of gum, rheumatism, abrasion, cuts and injuries etc. as folk medicine (Khanra 1997). Further, the essential oil contained in the leaves possesses antibacterial, antiprotozoan and antifungal properties (Hoque et al. 2011). Betel leaf is a product that is regularly consumed fresh and raw, but is difficult to decontaminate, as a result, like other fresh produces, can be a common vehicle of transmission of enteropathogenic bacteria (Berger et al. 2010). It is mainly produced in Bangladesh and India and exported worldwide. Due to the contamination of betel leaf with Salmonella spp., export of betel leaf has been reduced and sometimes suspended (Montanari 2015). Contamination of fresh produce like betel leaf with Salmonella spp. pose great public health risk to the consumer. Hence, research on contamination level and pattern of Salmonella spp. and effective decontamination process is of great urgency.

The present study aims to determine contamination level and pattern and to evaluate potential decontamination methods to neutralize Salmonella spp. contamination in betel leaf.

\section{Methods}

\section{Bacterial strains}

Salmonella Enteritidis ATCC 13076, S. Typhimurium ATCC 13311 and S. Typhi ATCC 65154 were used as positive culture in this study. Some environmental isolates $(n=15)$ of Salmonella were also included in the study to observe differences in gene expression. All the isolates were collected form culture collection pool of Industrial Microbiology Laboratory, IFST, BCSIR, Dhaka, Bangladesh.
Additionally, Salmonella spp. isolated from surface $(n=25)$ and internalized condition $(n=17)$ during this study were used.

\section{Sample collection}

In this experiment, a total of 100 samples was collected from different markets of Dhaka city, Bangladesh. Sterile polybags were used to collect the samples aseptically. Samples were collected as number of leaves (not weight). Twenty leaves were collected from each location. A total of ten sample was collected from each market. The sampling packs were marked properly and carried in ice box and transported to the laboratory within $3 \mathrm{~h}$. Experiments were carried out within 1-8 $\mathrm{h}$ after collecting the samples. All the samples were kept at $4{ }^{\circ} \mathrm{C}$ until these were analyzed.

\section{Identification and enumeration of Salmonella spp.}

Detection and identification of Salmonella spp. was done according to ISO/DIS 6579-1. Briefly, 25 g leaf sample was stomached with $225 \mathrm{ml} 1 \%$ peptone water and stomached sample was pre-enriched (Buffered peptone water) and enriched (tetrathionate broth and RV broth) and then selective media (XLD agar) was employed for specific detection according to the method. Isolates were further identified on the basis of biochemical tests (TSI agar/Urea agar/indole production/Voges-proskauer/Lysine decarboxylase). Enumeration of Salmonella spp. in betel leaf was done according to Husna et al. (2015). Briefly, samples were stomached in peptone water and serially diluted and plate on XLD agar plate by spread plate technique and incubated at $37^{\circ} \mathrm{C}$ for $24 \mathrm{~h}$. Salmonella spp. were counted and expressed as logCFU/g.

\section{Treatment of betel leaf with food disinfectants}

$\mathrm{H}_{2} \mathrm{O}_{2}(10 \%$, v/v), sodium hypochlorite (Sigma, USA) $(10 \%, \mathrm{w} / \mathrm{v})$ and commercial disinfectant (collected from local market) (1 \& 2) were used to treat betel leaves (collected from local market) contaminated with Salmonella spp. Briefly, the leaves (ten leave) were manually submerged into $200 \mathrm{ml}$ solutions of the disinfectants for $30 \mathrm{~min}$ and rinsed with sterile water for a couple of times. Then the leaves were cut into pieces and Salmonella spp. load was determined as described above. Salmonella-free leaves were submerged for $5 \mathrm{~min}$ in solution with $\sim 10^{5} \mathrm{cfu} / \mathrm{ml}$ of the bacteria and then analyzed as the same procedure to serve as controls.

\section{Detection of internalized Salmonella spp.}

Internalized Salmonella spp. has been detected and enumerated according to Franz et al. (Franz et al. 2007). Briefly, the surface of the collected whole leaf was disinfected with serial washing using tap water, $80 \%$ ethanol for $10 \mathrm{~s}, 1 \% \mathrm{AgNO}_{3}$ for $5 \mathrm{~min}$, tap water and finally 
rinsing with deionized water. Then the leaves were cut into pieces and analyzed according to the method described earlier. Salmonella-free leaves were submerged for $5 \mathrm{~min}$ in solution with $\sim 10^{5} \mathrm{cfu} / \mathrm{ml}$ of the bacteria and washed with water, ethanol and AgNO3 as described above and analyzed for both surface and internalized Salmonella spp. This serves to eliminate the presence of Salmonella as control to assure the presence of no Salmonella spp. in surface after washing.

Leaf internalization of ATCC strains was performed according to Kroupitski et al. (2009). Briefly, ATCC Salmonella strains was grown overnight in Luria-Bertani (LB) medium and cells were collected and washed twice with sterile distilled water and resuspended in sterile distilled water. Intact betel leaves (which were previously tested to be Salmonella free) were submerged in $30 \mathrm{ml}$ sterile distilled water in $50 \mathrm{ml}$ sterile tube (one piece per tube) for $30 \mathrm{~min}$. After that, sterile distilled water of the tube was replaced with $30 \mathrm{ml}$ Salmonella suspension $\left(\sim 10^{9} \mathrm{cfu} / \mathrm{ml}\right)$ and incubated for $2-3 \mathrm{~h}$ at $37^{\circ} \mathrm{C}$. After incubation, the leaves were washed twice with sterile distilled water to remove unattached bacteria. Internalized Salmonella spp. was enumerated as described earlier (Franz et al. 2007).

\section{Survivability of internalized Salmonella spp.}

Survivability of Salmonella spp. in internalized condition was determined according to Gorbatsevich et al. (2013). Betel leaf samples were sanitized (as described above) and cut into small pieces aseptically and inoculated with bacterial suspension with known cell concentration ( $\mathrm{LogCFU} / \mathrm{ml}$ ) and incubated at $37^{\circ} \mathrm{C}$ for 14 days. A portion $(10 \mathrm{~g})$ of the sample was analyzed each day to enumerate internalized Salmonella spp. as described earlier.

\section{Antibiotic resistance of internalized Salmonella spp.}

Antibiotic resistance pattern of the internalized Salmonella spp. were determined according to the method described by Kirby-Bauer (1966) on Mueller Hinton agar using commercial discs (Oxoid, UK). The following antibiotics with the disc strength were used: Ciprofloxacin (CIP, $5 \mu \mathrm{g})$, chloramphenicol $(\mathrm{C}, 30 \mu \mathrm{g})$, penicillin (P, 5 unit), tetracycline (TE, $30 \mu \mathrm{g})$, doxycycline (DO, $30 \mu \mathrm{g})$, neomycin (N, $30 \mu \mathrm{g})$, gentamycin (GN, $200 \mu \mathrm{g})$, ampicillin $(\mathrm{AM}, 10 \mu \mathrm{g})$, erythromycin $(\mathrm{E}, 15 \mu \mathrm{g})$ and nalidixic acid (NA, $30 \mu \mathrm{g})$. A control strain of E. coli ATCC 25922 was included in each plate. Antimicrobial breakpoints and interpretation were taken from the CLSI standards.

\section{Motility and biofilm formation of Salmonella spp.}

Motility of the isolates was determined according to the method of Sperandio et al. (2002). Isolates were grown overnight in LB broth at $37^{\circ} \mathrm{C}$ and was spot inoculated in center of $0.4 \%(\mathrm{w} / \mathrm{v}) \mathrm{LB}$ agar and incubated at $37{ }^{\circ} \mathrm{C}$ in static condition. Diameter of motility halos was measured to determine motility. Biofilm formation assays were performed following the method of Fakruddin et al. (2014). Bacterial suspension was inoculated into 96 well polystyrene microtitre plates and incubated overnight at $30^{\circ} \mathrm{C}$. After incubation, wells were washed with PBS and stained with $0.1 \%$ safranin for $30 \mathrm{~min}$ at $30{ }^{\circ} \mathrm{C}$. Adhered safranin was solubilized with dimethyl sulfoxide (DMSO) and absorbance of the wells were measured at $490 \mathrm{~nm}$ wavelength. Specific biofilm formation was then calculated.

\section{Virulence gene presence and expression}

Presence of six virulence associated gene in Salmonella spp. isolates has been determined. Isolates were grown in LB broth overnight at $37{ }^{\circ} \mathrm{C}$ and total RNA was extracted. Description and primer sequence of the genes are presented in Table 1. Virulence gene profile of leaf internalized Salmonella spp. was compared with that isolated from leaf surface and previously isolated environmental Salmonella strains. For determination of expression level of the virulence genes, total RNA was extracted from bacteria using Trizol reagent and cDNA was prepared using primescript $\mathrm{RT}$ reagent kit (TaKaRa Bio). Primers used for real time PCR are as follows: sefA (5'-GGCTTCGGTATCTGGTGGTGTG-3' and 5'-GTCA TTAATATTGGCTCCCTGAATA-3'), invA (5'-GCCTG CCGGAAGTATTGTTA-3' and 5'-GGAGTTTCTCCCC CTCTTCA-3'), hilA (5'-ATTAAGGCGACAGAGCTGG A-3' and 5'-GAATAGCAAACTCCCGACGA-3'), avrA (5'-GGAAACCGATCTCGAAATGA-3' and 5'-TGCTGG TTCGAACAAAATCA-3'), sopE (5'-CAACACACTTTCACCGAGGAAG-3' and 5'-GGTCTGGCTGGCGTAT GC-3') and spvC (5'-AATGAACTACGAAGTGGGCG-3' and 5'-TCAAACGATAAAACGGTTCCTC-3'), $16 \mathrm{~s}$ (5'TGTAGCGGTGAAATGCGTAG-3' and 5'-CAAGGGC

Table 1 Primer sequence of virulence genes detection by PCR

\begin{tabular}{|c|c|c|c|}
\hline Gene & Virulence factor & Primer sequence $\left(5^{\prime}-3^{\prime}\right)$ & $\begin{array}{l}\text { Base pair } \\
\text { (bp) }\end{array}$ \\
\hline \multirow[t]{2}{*}{ sefA } & \multirow[t]{2}{*}{ Fimbria } & GATACTGCTGAACGTAGAAGG & \multirow[t]{2}{*}{488} \\
\hline & & GCGTAAATCAGCATCTGCAGTAGC & \\
\hline \multirow[t]{2}{*}{ invA } & \multirow[t]{2}{*}{ Invasion } & GTGAAATTATCGCCACGTTCGGGCAA & \multirow[t]{2}{*}{284} \\
\hline & & TCATCGCACCGTCAAAGGAACC & \\
\hline \multirow[t]{2}{*}{ hilA } & \multirow[t]{2}{*}{ Invasion } & CTGCCGCAGTGTTAAGGATA & \multirow[t]{2}{*}{497} \\
\hline & & CTGTCGCCTTAATCGCATGT & \\
\hline \multirow[t]{2}{*}{ avrA } & \multirow{2}{*}{$\begin{array}{l}\text { Effector protein } \\
\text { of TTSS }\end{array}$} & GTTATGGACGGAACGACATCGG & \multirow[t]{2}{*}{385} \\
\hline & & ATTCTGCTTCCCGCCGCC & \\
\hline \multirow[t]{2}{*}{ sopE } & \multirow{2}{*}{$\begin{array}{l}\text { Effector protein } \\
\text { of TTSS }\end{array}$} & ACACACTITCACCGAGGAAGCG & \multirow[t]{2}{*}{398} \\
\hline & & GGATGCCTTCTGATGTTGACTGG & \\
\hline \multirow[t]{2}{*}{ spvC } & \multirow{2}{*}{$\begin{array}{l}\text { Plasmid - } \\
\text { virulence }\end{array}$} & CGGAAATACCATCTACAAATA & \multirow[t]{2}{*}{669} \\
\hline & & CCCAAACCCATACTTACTCTG & \\
\hline
\end{tabular}


ACAACCTCCAAG-3'). Transcripts were quantified by LightCycler (Roche Diagnostics) using SYBR Premix Ex Taq (TaKaRa Bio) in accordance with the manufacturer's instructions. The expression levels of each gene were normalized, with the $16 \mathrm{~S}$ rRNA gene as an internal control.

\section{Decontamination of internalized Salmonella spp.}

Decontamination with two commercial fruit and vegetable disinfection agent (anshin-yasai \& Yokosan; hereby denoted as commercial disinfectant 1 \& 2 respectively) was performed according to manufacturer's instruction. Information listed on the product revealed that active ingredient of disinfectant- 1 was calcium oxide and of disinfectant-2 was calcium bicarbonate. Decontamination with $\mathrm{H}_{2} \mathrm{O}_{2}$, sodium hypochlorite and ozonated water performed according to Bahreini et al. (2013). Ethanolic bark extract of Terminalia arjuna was prepared according to Mahbuba et al. (2012) and decontamination process was performed according to Orue et al. (2013). Briefly, selected chemicals and extracts were diluted with water at different concentrations. Artificially inoculated betel leaf were immersed in the suspension for $10 \mathrm{~min}$. After that, the leaves were washed with sterile water, ethanol and AgNO3 (as described above) and presence and load of Salmonella spp. were determined as described previously.

\section{Statistical analysis}

All experiments were done twice and all samples performed at least in triplicate. Data were analyzed by SPSS 17.0 (SPSS Inc., Chicago, Ill, USA).

\section{Result}

\section{Prevalence of Salmonella spp. in betel leaf}

A total of seventy seven (77) out of 100 samples were found to be contaminated with Salmonella spp. From the contaminated samples, 77 strains were isolated after pre-enrichment and enrichment and confirmed through biochemical and serological studies. The total percentages of occurrence were $77 \%$. Betel leaf collected from all areas showed to be contaminated with Salmonella spp. (Fig. 1a). Prevalence observed in this study were $28.5 \%, 19.5 \%, 15.6 \%, 10.4 \%, 9.1 \%, 10.4 \%$ and $6.5 \%$ representing Salmonella Enteritidis, S. Typhimurium, S. Paratyphi, $S$. Schottmuelleri, $S$. Gallinarum, $S$. Choleraesuis and $S$. Bongori respectively (Fig. 1b).

\section{Treatment of betel leaf with food disinfectants}

Naturally contaminated betel leaves were washed with commercial food disinfectant $1 \& 2, \mathrm{H}_{2} \mathrm{O}_{2}$ and Sodium hypochlorite. Commercial disinfectant 1 and 2 showed $3.29 \log$ and $3.87 \log$ reduction respectively, while that of sodium hypochlorite and $\mathrm{H}_{2} \mathrm{O}_{2}$ showed a lower $\log$

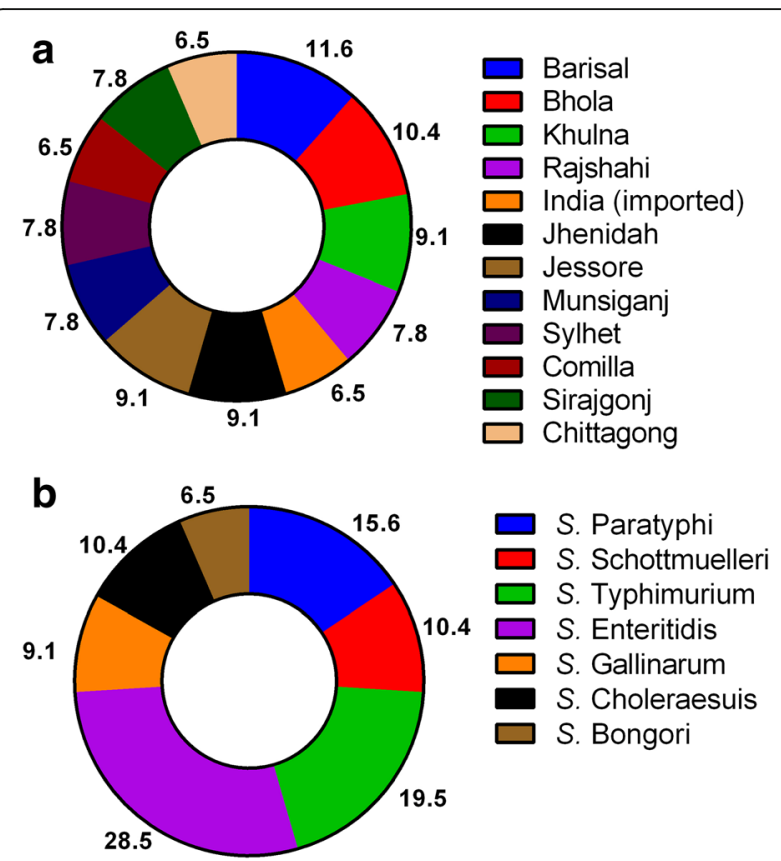

Fig. 1 Prevalence of Salmonella spp. in betel leaf. a depicts regional distribution of betel leaf samples infected with Salmonella spp. b shows serovar distribution of Salmonella spp. in infected betel leaf

reduction (2.37 log and $2.48 \log$ respectively) (Table 2). Control leaves (surface inoculated Salmonella-free leaves treated with same treatments) were found to be negative for the presence of Salmonella spp. This result indicates that surface disinfection based treatment were not effective to decontaminate Salmonella spp. from betel leaf. Occurrence of internalized Salmonella spp. in betel leaf was also determined (Table 3). Surface decontamination can reduce Salmonella loads by $1.97 \mathrm{log}$ and treatment with disinfectants after surface decontamination reduce Salmonella loads by $2.78 \mathrm{log}$, indicating that Salmonella spp. may be internalized in inner parts of the leaf.

\section{Internalization potential of isolate and ATCC strain}

Comparison of internalization potential of two Salmonella strains isolated from internalized condition in betel leaf with three (3) ATCC Salmonella strains showed that the isolates pose better internalization potential than the ATCC strains (Table 4). Salmonella isolates from internalized condition showed considerable internalization potential. Approx. $6.7 \log \mathrm{CFU}$ was found to be internalized in case of $S$. Typhimurium isolate and approx. 7.4 $\log \mathrm{CFU}$ was internalized in case of $S$. Typhi isolate (Table 4). In contrast, ATCC isolates showed very little internalization (approx. $1.2 \log \mathrm{CFU}$ for $S$. Enteritidis ATCC 13076 and $1.6 \log$ CFU for $S$. Typhi ATCC 65154) (Table 3). Control leaves were found to be free of any internalized Salmonella spp. 
Table 2 Disinfection of contaminated betel leaves with different sanitizer

\begin{tabular}{lcc}
\hline $\begin{array}{l}\text { Treatment } \\
\text { name }\end{array}$ & $\begin{array}{l}\text { Salmonella count } \\
\text { (log cfu/g) } \\
\text { before treatment }\end{array}$ & $\begin{array}{l}\text { Salmonella count } \\
\text { (log cfu/g) } \\
\text { after treatment }\end{array}$ \\
\hline $\begin{array}{l}\text { Commercial } \\
\text { disinfectant-1 (10\%) }\end{array}$ & $10.75 \pm 0.53$ & $7.46 \pm 0.37$ \\
Commercial disinfectant-2 (10\%) & $10.68 \pm 0.09$ & $6.81 \pm 0.48$ \\
$\mathrm{H}_{2} \mathrm{O}_{2}(10 \%)$ & $10.52 \pm 0.32$ & $8.15 \pm 0.81$ \\
Sodium hypochlorite (10\%) & $10.31 \pm 0.72$ & $7.83 \pm 0.19$ \\
\hline
\end{tabular}

Antibiotic susceptibility and Survivability comparison of internalized Salmonella

Antibiotic susceptibility pattern on internalized Salmonella isolates $(n=17)$ was shown in Fig. 2 and it shows the isolates pose moderate antibiotic resistance. Comparison of survivability of Salmonella Typhi isolate and ATCC strains in internalized condition in betel leaf is shown in Fig. 3. All the isolates were able to internalize and wild isolates internalized in a greater degree but survivality within the tissue seems to be the same. No significant differences were observed. After 14 days incubation, $6.72 \operatorname{logCFU}$ Salmonella spp. were viable in internalized condition (initial count at day 0 was 8.31 $\log$ CFU). In case of ATCC Salmonella strain, 5.23 $\operatorname{logCFU}$ Salmonella were viable after 14 days incubation (initial count $7.58 \log$ CFU) (Fig. 3).

\section{Motility and biofilm forming capability of the isolated Salmonella}

Biofilm formation mediates survival of bacteria in internalized condition (Kroupitski et al. 2009) and motility mediates translocation in plant tissues (Warriner et al. 2003). Biofilm formation and motility of internalized Salmonella spp. isolated from betel leaf as well as of ATCC isolates was determined. Isolates showed better biofilm formation ability $(\mathrm{SBF}>1)$ than the reference cultures $(\mathrm{SBF}<1)$ (Table 5$)$. Motility of the isolates were also higher $(>40 \mathrm{~mm})$ than that of reference cultures $(<20 \mathrm{~mm})$. These data coincide with the better survivability of the isolates in internalized condition than the ATCC cultures.

\section{Virulence gene presence and expression}

sefA and $i n v A$ are reported to impart virulence in Salmonella spp. sefA and invA gene were present in $64.7 \%$

Table 3 Occurrence of internalized Salmonella spp. in betel leaf

\begin{tabular}{ll}
\hline Betel leaf & $\begin{array}{l}\text { Salmonella count } \\
(\mathrm{log} C F U / g)\end{array}$ \\
\hline Without surface decontamination & $9.45( \pm 0.33)$ \\
With surface decontamination (Internalized) & $7.48( \pm 1.03)$ \\
$\begin{array}{l}\text { Treated with disinfectants \& without surface } \\
\text { decontamination }\end{array}$ & $6.67( \pm 0.11)$ \\
\hline
\end{tabular}

Table 4 Internalization potential of Salmonella spp. isolated from betel leaf

\begin{tabular}{lcc}
\hline Strain & $\begin{array}{l}\text { Inoculum } \\
\text { (log cfu/g) }\end{array}$ & $\begin{array}{l}\text { Internalized Salmonella } \\
\text { (log cfu/g) }\end{array}$ \\
\hline $\begin{array}{l}\text { S. Typhimurium (Isolated from } \\
\text { internalized condition) }\end{array}$ & $10.1 \pm 0.33$ & $7.7 \pm 0.52$ \\
$\begin{array}{l}\text { S. Typhi (Isolated from internalized } \\
\text { condition) }\end{array}$ & $10.1 \pm 0.73$ & $8.4 \pm 0.73$ \\
S. Enteritidis ATCC 13076 & $10.3 \pm 0.19$ & $2.2 \pm 0.89$ \\
S. Typhimurium ATCC 13311 & $10.0 \pm 0.27$ & $2.6 \pm 0.12$ \\
S. Typhi ATCC 65154 & $10.1 \pm 0.44$ & $1.86 \pm 0.21$ \\
\hline
\end{tabular}

and $76.5 \%$ internalized Salmonella spp. isolate respectively in comparison to surface (72\% \& 60\%) and environmental (63.6\% \& 68.2\%) Salmonella spp. isolates. Other virulence associated genes such as hilA, avrA and sopE were present in $64.7 \%, 52.9 \%$ and $64.7 \%$ of internalized isolate respectively. These three genes were present in very low number of surface Salmonella isolates (4\%, 4\% \& 16\%, respectively) and environmental Salmonella isolates $(18.2 \%, 18.2 \%$ \& $13.6 \%$ respectively). However, prevalence of $s p v C$ gene in all type of isolate is very low (Fig. 4). The expression level of the virulence associated genes in internalized Salmonella spp. were much higher than that in surface and environmental isolates (Fig. 5). Elevated expression of sefA and invA in internalized Salmonella spp. suggest virulence potential of these isolates. Increased expression of T3SS related genes (such as hilA, avrA, sopE and sopC) indicates hyper-activation of T3SS in internalized isolates contributing better survival in internalized conditions.

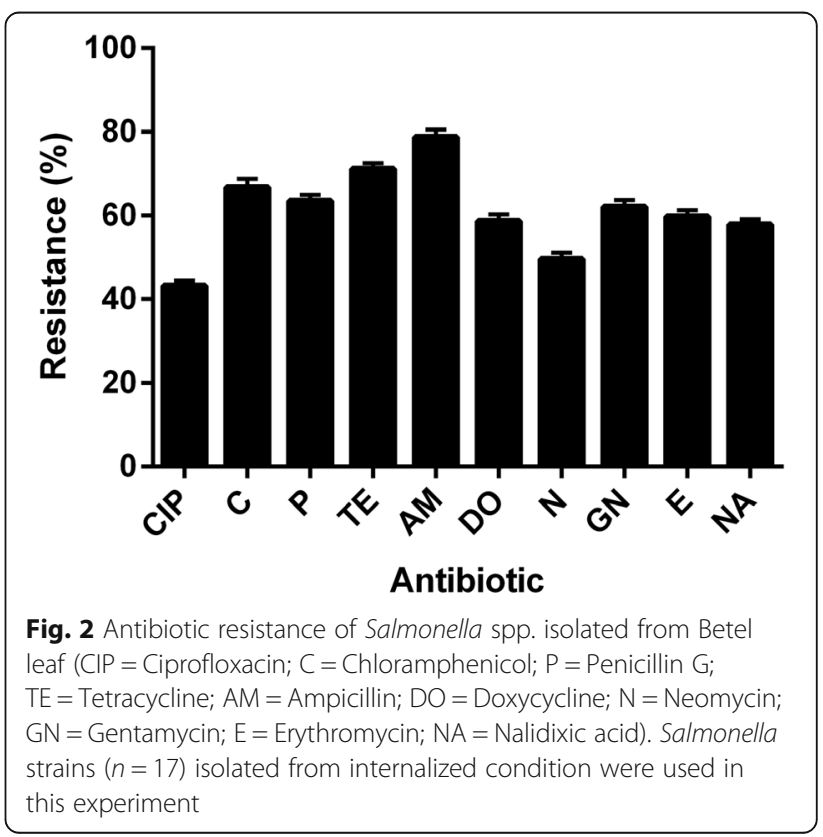




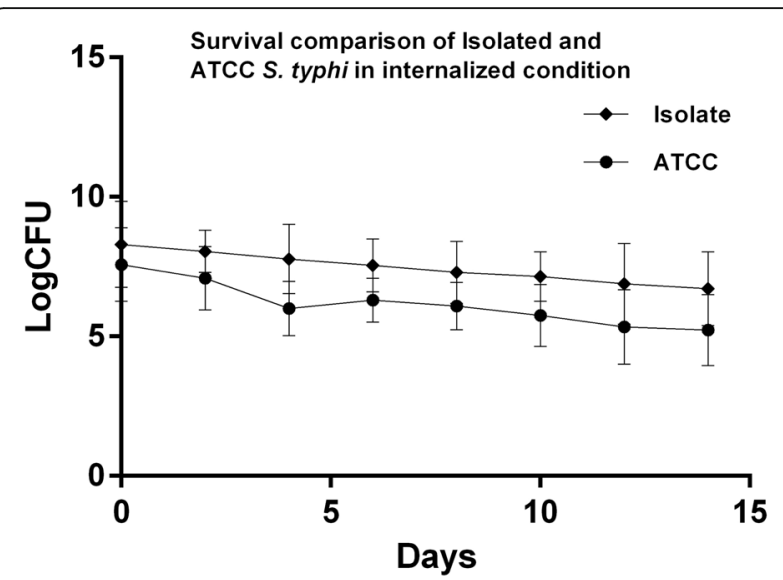

Fig. 3 Survival potential of Salmonella spp. in internalized condition

\section{Decontamination treatment of internalized Salmonella}

Decontamination method of internalized Salmonella spp. has been performed and showed in Table 6. Commercial agents ( $1 \& 2$ ) have been found to have limited decontamination effect (around $1.2 \log$ and 2 log reduction respectively) on internalized Salmonella spp. with increasing efficacy at elevated concentration. $\mathrm{H}_{2} \mathrm{O}_{2}$ showed almost similar efficacy compare with commercial agents (1.9 log reduction at $10 \%$ concentration). Washing leaves with internalized bacteria with ozonated water showed better neutralization effect (3 log reduction) than both commercial agents and $\mathrm{H}_{2} \mathrm{O}_{2}$. Betel leaves treated with Ethanolic bark extract of Terminalia arjuna reduced internalized Salmonella spp. significantly. There was a log reduction of 3.8 at $5 \%$ concentration, $4.8 \mathrm{log}$ at $10 \%$ concentration and $4.6 \log$ reduction at $15 \%$ concentration (Table 6 ).

\section{Discussion}

A total of 100 betel leaf samples were collected from different regions, $77 \%$ of the samples, were found to be contaminated with Salmonella spp. Regional distribution of contaminated betel leaf and species distribution of Salmonella spp. was shown in Fig. 1. Several studies has also reported presence of Salmonella spp. in betel leaf earlier. Singla et al. (2009) and Singh et al. (2006) have

Table 5 Comparison of biofilm formation and motility of Internalized and ATCC Salmonella spp.

\begin{tabular}{lcc}
\hline Strain & $\begin{array}{c}\text { Specific biofilm } \\
\text { formation (SBF) }\end{array}$ & $\begin{array}{l}\text { Motility } \\
\text { (diameter in mm) }\end{array}$ \\
\hline Internalized S. Typhimurium & $1.34 \pm 0.14$ & $42 \pm 1.8$ \\
Internalized S. Typhi & $1.53 \pm 0.21$ & $45 \pm 2.2$ \\
S. Enteritidis ATCC 13076 & $0.76 \pm 0.31$ & $21 \pm 1.2$ \\
S. Typhimurium ATCC 13311 & $0.81 \pm 0.18$ & $18 \pm 1.2$ \\
S. Typhi ATCC 65154 & $0.51 \pm 0.08$ & $20 \pm 0.9$ \\
\hline
\end{tabular}

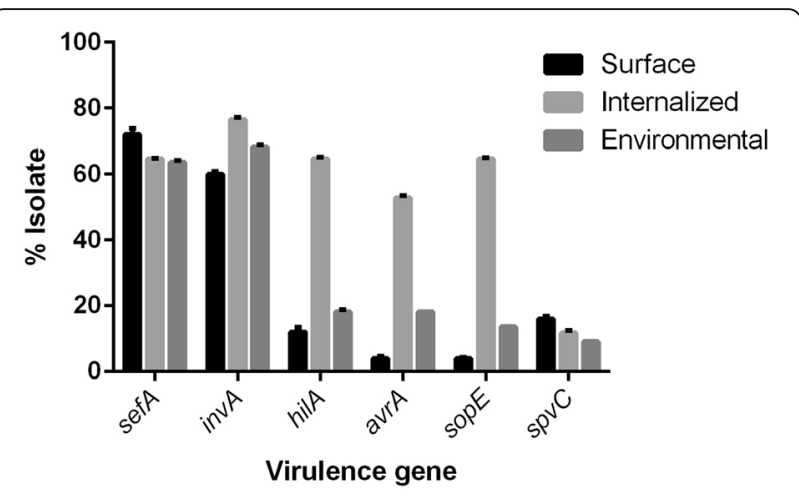

Fig. 4 Virulence gene profile of internalized Salmonella spp. $(n=17)$ in comparison with surface $(n=25)$ and environmental isolates $(n=15)$

reported Salmonella spp. in betel leaf of Indian origin and Husna et al. (2015) reported Salmonella spp. in betel leaf of Mymensingh region, Bangladesh and Salmonella count was around 5 log in their samples.

Contaminated betel leaves were washed with four surface disinfectants (anshin-yasai, yokosan, $\mathrm{H}_{2} \mathrm{O}_{2}$ and sodium hypochlorite) and results showed that these agents cannot fully decontaminate the betel leaf though reduced Salmonella spp. level. From these results, the possibility arises that Salmonella spp. were present not only in surface, but also in the internal parts of the betel leaf, hence imparting its resistance were to these surface disinfectants. Internalized Salmonella spp. in betel leaf samples were enumerated and result showed that a significant portion of total Salmonella spp. in the leaves are internalized.

Many previous researchers reported internalization of pathogenic bacteria, including Salmonella spp. into plant leaves. Goldberg et al. (2011) reported internalization of Salmonella Typhimurium in detached leaves of seven

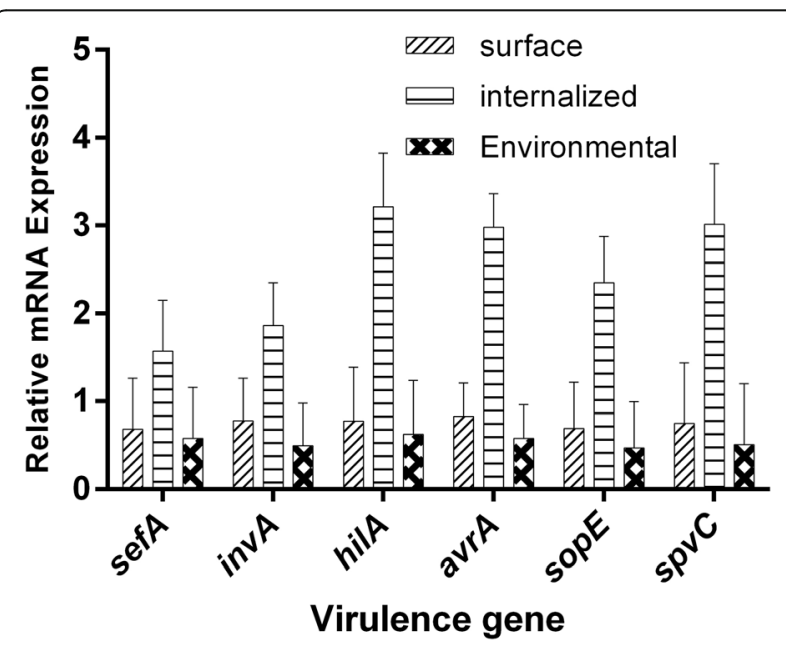

Fig. 5 Expression of virulence gene in internalized Salmonella spp. $(n=17)$ in comparison with surface $(n=25)$ and environmental isolates $(n=15)$ 
Table 6 Decontamination of internalized Salmonella spp. from betel leaf

\begin{tabular}{|c|c|c|c|c|}
\hline \multirow[t]{2}{*}{ Treatment } & \multirow[t]{2}{*}{ Conc. } & \multicolumn{2}{|c|}{$\begin{array}{l}\text { Salmonella count } \\
(\log \mathrm{cfu} / \mathrm{g})\end{array}$} & \multirow[t]{2}{*}{$\begin{array}{l}\text { Log } \\
\text { Reduction (approx.) }\end{array}$} \\
\hline & & $\begin{array}{l}\text { Before } \\
\text { treatment }\end{array}$ & $\begin{array}{l}\text { After } \\
\text { treatment }\end{array}$ & \\
\hline \multirow[t]{3}{*}{ Commercial agent-1 } & $5 \%$ & $10.1 \pm 0.94$ & $8.9 \pm 1.14$ & 1.2 \\
\hline & $10 \%$ & $10.6 \pm 0.75$ & $9.2 \pm 1.21$ & 1.4 \\
\hline & $15 \%$ & $10.9 \pm 0.89$ & $8.2 \pm 1.09$ & 1.7 \\
\hline \multirow[t]{3}{*}{ Commercial agent-2 } & $5 \%$ & $10.2 \pm 1.05$ & $8.2 \pm 0.97$ & 2 \\
\hline & $10 \%$ & $10.4 \pm 1.12$ & $7.9 \pm 0.89$ & 2.5 \\
\hline & $15 \%$ & $10.1 \pm 1.23$ & $8.3 \pm 0.76$ & 1.8 \\
\hline \multirow[t]{3}{*}{$\mathrm{H}_{2} \mathrm{O}_{2}$} & $5 \%$ & $9.7 \pm 0.88$ & $8.9 \pm 0.81$ & 0.8 \\
\hline & $10 \%$ & $10.1 \pm 0.69$ & $8.2 \pm 1.11$ & 1.9 \\
\hline & $15 \%$ & $9.9 \pm 1.31$ & $8.1 \pm 1.15$ & 1.8 \\
\hline \multirow[t]{3}{*}{ TAEB } & $5 \%$ & $10.7 \pm 1.12$ & $6.9 \pm 1.07$ & 3.8 \\
\hline & $10 \%$ & $11.2 \pm 0.83$ & $6.4 \pm 0.89$ & 4.8 \\
\hline & $15 \%$ & $10.9 \pm 0.84$ & $6.3 \pm 0.96$ & 4.6 \\
\hline $\begin{array}{l}\text { Ozonated water } \\
(2 \mathrm{ppm})\end{array}$ & $\mathrm{N} / \mathrm{A}$ & $10.5 \pm 0.95$ & $7.5 \pm 1.10$ & 3 \\
\hline
\end{tabular}

vegetables and fresh herbs. Hou et al. (2013) reported that bacteria such as Salmonella, E. coli O157:H7, Bacillus, Enterobacter, Pseudomonas and Pantoea can internalize into lettuce leaves naturally through wounds or via roots and stomata. Avila-Quezada et al. (2010) showed that Salmonella spp. can internalize and migrate into plant tissues such as seeds, fruits, leaves, roots and stems and survive for extended periods in internalized condition. Guo et al. (2002) reported that Salmonella spp. can enter fruits and other plant parts through abrasions. Guo et al. (2001) also reported short distance migration of Salmonella spp. into plant. Zheng et al. (2013) also reported that Salmonella spp. has the ability to internalize into tomato plants through roots, leaves and blossoms. Internalization of Salmonella spp. has also been reported in mangoes (Penteado et al. 2004), tomatoes (Buchanan et al. 1999), apple (Zhuang et al. 1995), lettuce (Reina et al. 2002), and sweet basil (Gorbatsevich et al. 2013). Internalization may occur naturally as reported in these studies, or may occur during washing (due to immersion) at post-harvest stages (Gomez-Lopez et al. 2013).

Internalization efficiency of reference Salmonella culture (S. Typhimurium ATCC 13311, S. Enteritidis ATCC 13076 and S. Typhi ATCC 65154) and S. Typhi and S. Typhimurium isolated from betel leaf (leaf with internalized Salmonella) has been compared and it was found that the isolates pose better internalization potential (6.7-7.4 $\log$ CFU/gm) when compared with the ATCC cultures (0.86-0.6 logCFU/gm). All the isolates were able to internalize and wild isolates internalized in a greater degree but survivality within the tissue seems to be the same. Salmonella spp. isolates from betel leaf showed better biofilm formation ability $(\mathrm{SBF}>1)$ and motility $(>40 \mathrm{~mm})$ than ATCC cultures $(\mathrm{SBF}<1$ and motility $<20 \mathrm{~mm})$. Results indicate that the isolated internalized Salmonella spp. have moderate resistance to commonly used antibiotics (Fig. 2) but antibiotic resistance were lower compared to the reports of other previous researchers who reported higher resistance in Salmonella spp. isolated from different food and poultry samples of Bangladesh (Nipa et al. 2011; Mahbuba et al. 2012).

Internalized bacteria can evade disinfection, thus detailed study on the mechanism of internalization as well as on plant and environmental factors affecting internalization is needed to devise remediation methods ensuring safety of the fresh produces (Ge et al. 2013). Mechanism of internalization of bacteria in the plant has not been elucidated clearly till now. Generally, internalization is an active process dependent upon the plant and the pathogen (Hora et al. 2005). Bacteria can internalize through root during cultivation and through the stomata of leaf during pre-/post-harvest (Hoelzer et al. 2014). Bacterial internalization is influenced by the surface properties of the leaf, including morphology, chemical constituents and metabolic activities (Leveau 2009). Pathogenic bacteria can penetrate internal tissue of the plant through the roots (Solomon et al. 2002), and seeds (Islam et al. 2004) for further translocation and survival in the edible aerial plant tissues (Solomon et al. 2002). Some studies reported that bacterial strains varied widely in their endophytic colonization abilities, which could be related to the plant defense mechanisms that targeted bacterial extracellular components (Dong et al. 2003; Iniguez et al. 2005). Water used for the washing of the fruits can be contaminated by the pathogens while acting as the source of the internalization of the pathogens through the lenticels, stomata and the injured parts (Reina et al. 2002).

It has been reported previously that many virulence associated genes mediate internalization and persistence of Salmonella spp. in plant. sefA gene is involved in attachment with plant tissue while $i n v A$ gene is involved in epithelial invasion of plant tissue. Of all the virulence genes, type III secretion system (TTSS) associated genes are most important for internalization of Salmonella (Schikora et al. 2012). hilA gene product is a central regulator of TTSS and also involved in epithelial invasion. avrA gene product is an effector protein of TTSS and mediate Salmonella internalization and persistence by suppressing the host inflammatory response. sopE gene product contributes invasion through generation of membrane deformations. $s p v C$ gene (located on 
virulence plasmid) product promotes rapid growth and survival of Salmonella spp. within host cells (Borges et al. 2013). Results showed that the prevalence of invasion (sefA and $i n v A$ ) and TTSS associated genes (hila, avrA and $\operatorname{sop} E$ ) are high in internalized Salmonella isolates which indicates probable mechanisms of internalization of the isolates. It can be postulated that TTSS play central role in the internalization and persistence of Salmonella spp. in betel leaf. Prevalence of hilA and avrA gene was more in internalized $S$. Enteritidis, whereas prevalence of sopE gene is more prevalent in $S$. Typhimurium and prevalence of $s p \nu C$ gene was prevalent in $S$. Paratyphi and $S$. Gallinarum.

Decontamination efficiency of different food disinfectants at different concentrations against internalized Salmonella spp. has been evaluated. Commercial disinfectants (anshin-yasai and yokosan) as well as $\mathrm{H}_{2} \mathrm{O}_{2}$ are found to have poor efficacy (log reduction around 2 CFU/gm). Ozonated water showed better decontamination efficacy (log reduction around $3 \mathrm{CFU} / \mathrm{gm})$. Singla et al. (2009) reported that treatment of betel leaf with $2 \%$ acetic acid reduced artificially surface-contaminated Salmonella spp. by 4 log. Singla (2011) showed combined treatment of $2 \%$ malic acid along with $2 \mathrm{ppm}$ ozone significantly reduced Salmonella Typhimurium by $7 \log$ in turnip and reduced Cronobacter sakazakii by $6.8 \mathrm{log}$ in betel leaf. Husna et al. (2015) showed treatment of betel leaf with sorbitol and sodium benzoate can be effective to reduce Salmonella spp. in betel leaf though log reduction was very low compared to other studies. Hadjok et al. (2008) reported UV light (254 nm) combined with $\mathrm{H}_{2} \mathrm{O}_{2}$ can reduce contamination levels of human pathogens (Escherichia coli O157:H7, Pectobacterium carotovora, Pseudomonas fluorescens and Salmonella) on or within (internalized) fresh produces but reduction of internalized pathogen was around half of that for surface pathogens. Orue et al. (2013) reported that extracts from oregano and lime are as effective as chlorine based disinfectants for decontamination of Salmonella, Shigella and Escherichia coli O157:H7 on leafy vegetables. In our previous studies, we found ethanolic extract of Terminalia arjuna stem bark has antibacterial activity against Vibrio cholerae (Fakruddin et al. 2011) and Salmonella spp. (Mahbuba et al. 2012). In this study, ethanolic extract of Terminalia arjuna stem bark fared better reducing potential than the rest of the treatments (log reduction around $4.5 \mathrm{CFU} / \mathrm{gm}$ ) (Table 6). Plant extract contains essential oil with antibacterial activity and could be useful for decontamination of internalized Salmonella spp.

Many reports exist describing internalization of bacteria in to plants through artificial inoculation experiments whereas report of incidence of natural internalization was still very few. Despite some limitations of this study such as lack of fluorescence microscopy and efficient method of isolation of nucleic acids directly from leaf, this study results indicate occurrence of natural ingression of Salmonella spp. in betel leaf. Future research is needed to further elucidate detailed mechanism of internalization of Salmonella spp. in betel leaf as well as other plant.

\section{Conclusion}

The present study provide indications of natural internalization of Salmonella spp. in betel leaf, though the mechanisms of internalization is yet to be elucidated. The internalization of pathogenic bacteria like Salmonella spp. is a public health concern because a small number of surviving cells can be potentially lethal. As Internalized Salmonella spp. in betel leaf evade surface disinfection, elucidation of internalization mechanisms and factors (plant, bacterial and environmental) affecting internalization into betel leaf is needed to ensure the safety of this economically important fresh produce. Efficient decontamination method has to be discovered to reduce the risk associated with internalized Salmonella in betel leaf.

\section{Abbreviations}

ATCC: American Type Culture Collection; CFU: Colony forming unit: DMSO: Demethyl sulfoxide; LB: Luria Bertani; PCR: Polymerase chain reaction; RT: Reverse transcription; SBF: Specific biofilm formation; TSI: Triple sugar iron; TTSS: Type 3 secretion system; XLD: Xylose lysine deoxycholate

\section{Acknowledgements}

The authors acknowledge the help of Ms. Sumaiya Islam, Scientific Officer, Industrial microbiology laboratory, IFST, BCSIR in conducting this study.

\section{Funding}

No external funding received.

\section{Author's contributions}

MF and MMA designed the study. MF, NH and RS performed all the experiments. MKI and MMA supervised the study. MF wrote the first draft of the manuscript and all authors read and approve the final manuscript.

\section{Competing interests}

The authors declare that they have no competing interests.

\section{Publisher's Note}

Springer Nature remains neutral with regard to jurisdictional claims in published maps and institutional affiliations.

\section{Author details}

${ }^{1}$ Industrial Microbiology Laboratory, Institute of Food Science and Technology (IFST), Bangladesh Council of Scientific and Industrial Research (BCSIR), Dr. Kudrat I Khuda Road, Dhanmondi, Dhaka 1205, Bangladesh. ${ }^{2}$ Department of Genetic Engineering \& Biotechnology, Shahjalal University of Science \& Technology, Sylhet 3114, Bangladesh.

Received: 8 September 2016 Accepted: 28 March 2017

Published online: 04 April 2017

\footnotetext{
References

Auty M, Duffy G, O'Beirne D, McGovern A, Gleeson E, Jordan K. In situ localization of Escherichia coli 0157:H7 in food by confocal scanning laser microscopy. J Food Protect. 2005;68:482-6.

Avila-Quezada G, Sanchez E, Gardea-Bejar AA, Acedo-Felix E. Salmonella spp. and Escherichia coli: survival and growth in plant tissue. New Zealand J Crop Horticul Sci. 2010;38(2):47-55.
} 
Bahreini M, Jahed E, Lotfian F, Khaneghah AM, Ghaderifarah M. The efficacy of ozonated water on reduction of four food borne pathogens and microbial quality of lettuce. J Appl Sci Agricul. 2013;8(7):1425-30.

Bauer AW, Kirby WM, Sheris JC, Turck M. Antibiotic susceptibility testing by a standardized single disc method. Am J Clin Path. 1996;45:149-58.

Berger CN, Sodha SV, Shaw RK, Griffin PM, Pink D, Hand P, Frankel G. Fresh fruit and vegetables as vehicles for the transmission of human pathogens. Environ Microbiol. 2010;12(9):2385-97.

Bernstein N. Potential for contamination of crops by microbial human pathogens introduced to the soil by irrigation with treated-effluent. Israel J Plant Sci. 2011:59:115-23.

Bernstein N, Sela S, Neder-Lavon S. Assessment of contamination potential of lettuce by Salmonella enterica serovar Newport added to the plant growing medium. J Food Protect. 2007a;70:1717-22.

Bernstein N, Sela S, Neder-Lavon S. Effect of irrigation regimes on persistence of Salmonella enterica serovar Newport in small experimental pots designed for plant cultivation. Irrig Sci. 2007b;26:1-8.

Borges KA, Furian TQ, Borsoi A, Moraes HLS, Salle CTP, Nascimento VP. Detection of virulence-associated genes in Salmonella enteritidis isolates from chicken in south of Brazil. Pesqui Vet Bras. 2013;33(12):1416-22.

Buchanan RL, Edelson SG, Miller RL, Sapers GM. Contamination of intact apples after immersion in an aqueous environment containing Escherichia coli 0157: H7. J Food Protect. 1999:62(5):444-50.

Dong Y, Iniguez AL, Ahmer BM, Triplett EW. Kinetics and strain specificity of rhizosphere and endophytic colonization by enteric bacteria on seedlings of Medicago sativa and Medicago truncatula. Appl Environ Microbiol. 2003;69(3):1783-90.

Donkor ES, Lanyo R, Kayang BB, Quaye J, Edoh DA. Internalizations of microbes in vegetables: Microbial load of Ghanaian vegetables and the relationship with different water sources of irrigation. Pakistan J Biol Sci. 2010;13(17):857-61.

Erickson MC, Webb CC, Diaz-Perez JC, Phatak SC, Silvoy JJ, Davey L, et al. Surface and internalized Escherichia coli 0157:H7 on field-grown spinach and lettuce treated with spray-contaminated irrigation water. J Food Protect. 2010;73:1023-29.

Fakruddin M, Alam KMA, Mazumdar RM, Islam S, Nipa MN, Iqbal A, Bhuiyan HR. Anti-bacterial activity of the Extract of Terminalia arjuna against multi antibiotic resistant Vibrio cholerae. J Sci Res. 2011;3(1):129-37.

Fakruddin M, Mannan KSB, Mazumdar RM. Correlation between in vitro biofilm formation and virulence properties of extra-intestinal pathogenic Escherichia coli (EXPEC). OnLine J Biol Res. 2014;14(4):261-70.

Franz E, Visser AA, Van Diepeningen AD, Klerks MM, Termorshuizen AJ, Van Bruggen AHC. Quantification of contamination of lettuce by GFP-expressing Escherichia coli 0157:H7 and Salmonella enterica serovar Typhimurium. Food Microbiol. 2007;24:106-12.

Ge C, Bohrerova Z, Lee J. Inactivation of internalized Salmonella Typhimurium in lettuce and green onion using ultraviolet $C$ irradiation and chemical sanitizers. J Appl Microbiol. 2013;114:1415-24.

Goldberg D, Kroupitski Y, Belausov E, Pinto R, Sela S. Salmonella Typhimurium internalization is variable in leafy vegetables and fresh herbs. Intl J Food Microbiol. 2011;145:250-7

Gomes C, Da Silva P, Moreira RG, Castell-Perez E, Ellis EA, Pendleton M. Understanding $E$. coli internalization in lettuce leaves for optimization of irradiation treatment. Intl J Food Microbiol. 2009:135:238-47.

Gómez-López VM, Alicia M, Ana A, Beuchat LR, GIL MI. Postharvest. Handling Conditions Affect Internalization of Salmonella in Baby Spinach during Washing. J. Food Prot.. 2013;76(7):1145-51.

Gorbatsevich E, Saldinger SS, Pinto R, Bernstein N. Root internalization, transport and in-planta survival of Salmonella enterica serovar Newport in sweet basil. Environ Microbiol Rep. 2013;5(1):151-9.

Gorny J. Microbial contamination of fresh fruits and vegetables. In: Sapers GM, Gorny JR, Yousef AE, editors. Microbiology of Fresh Produce. New York: CRC Taylor and Francis; 2006. p. 3-32.

Gu G, Cevallos-Cevallos JM, van Bruggen AHC. Ingress of Salmonella enterica Typhimurium into Tomato Leaves through Hydathodes. PLoS One. 2011:8(1):e53470

Guo X, Chen J, Brackett RE, Beuchat LR. Survival of Salmonella on and in tomato plants from the time of inoculation at flowering and early stages of fruit development through fruit ripening. Appl Environ Microbiol. 2001;67(10):4760-4.

Guo X, Van lersel MW, Chen J, Brackett RE, Beuchat LR. Evidence of association of Salmonellae with tomato plant grown hydroponically in inoculated nutrient solution. Appl Environ Microbiol. 2002;68(7):3639-43.
Hadjok C, Mittal GS, Warriner K. Inactivation of human pathogens and spoilage bacteria on the surface and internalized within fresh produce by using a combination of ultraviolet light and hydrogen peroxide. J Appl Microbiol. 2008;104:1014-24.

Hirneisen KA, Sharma M, Kniel KE. Human enteric pathogen internalization by root uptake into food crops. Foodborne Pathogen Dis. 2012;9(5): 395-405.

Hoelzer K, Pouillot R, Van Doren JM, Dennis S. Reduction of Listeria monocytogenes contamination on produce-A quantitative analysis of common liquid fresh produce wash compounds. Food Control. 2014;46:430-40.

Hoque MM, Ratilla S, Shishir MA, Bari ML, Inatsu Y, Kawamoto S. Antibacterial activity of ethanol extract of betel leaf (Piper betle L.) against some food borne pathogens. Bangladesh J Microbiol. 2011;28(2):58-63.

Hora R, Warriner K, Shelp BJ, Griffiths MW. Internalization of Escherichia coli O157: H7 following biological and mechanical disruption of growing spinach plants. J Food Protect. 2005;68(12):2506-9.

Hou Z, Fink RC, Radtke C, Sadowsky MJ, Diez-Gonzalez F. Incidence of naturally internalized bacteria in lettuce leaves. Intl J Food Microbiol. 2013;62:260-5.

Husna AA, Islam MA, Rahman MT, Khatun MM. Efficacy of vinegar, sorbitol and sodium benzoate in mitigation of Salmonella contamination in betel leaf. J Adv Vet Anim Res. 2015;2(2):190-4.

Ibarra-Sanchez LS, Alvarado-Casillas S, Rodriguez-Garcia MO, Martinez-Gonzales $\mathrm{NE}$, Castillo A. Internalization of bacterial pathogens in tomatoes and their control by selected chemicals. J Food Protect. 2004;67(7):1353-8.

Iniguez AL, Dong Y, Carter HD, Ahmer BM, Stone JM, Triplett EW. Regulation of enteric endophytic bacterial colonization by plant defenses. Mol Plant Microbe Interact J. 2005:18(2):169-78.

Islam M, Doyle MP, Phatak SC, Millner P, Jiang X. Persistence of enterohemorrhagic Escherichia coli 0157:H7 in soil and on leaf lettuce and parsley grown in fields treated with contaminated manure composts or irrigation water. J Food Protect. 2004;67(7):1365-70.

ISO/DIS 6579-1. Microbiology of the food chain-Horizontal method for the detection, enumeration and serotyping of Salmonella_-Part 1: Horizontal method for the detection of Salmonella spp. (http://www.iso.org/iso/home/ store/catalogue_tc/catalogue_detail.htm?csnumber=56712).

Jablasone J, Warriner K, Griffiths M. Interactions of Escherichia coli 0157:H7, Salmonella typhimurium and Listeria monocytogenes plants cultivated in a gnotobiotic system. Intl J Food Microbiol. 2005;99:7-18.

Khanra S. Paan Vittik Silpakendra (In Bengali). "Betel Leaf Based Industry". Nabanna Bharati. 1997;30(2):169.

Kroupitski Y, Golberg D, Belausov E, Pinto R, Swartzberg D, Granot D, Sela S. Internalization of Salmonella enterica in leaves is induced by light and involves chemotaxis and penetration through open stomata. Appl Environ Microbiol. 2009;75(19):6076-86.

Lapidot A, Romling U, Yaron S. Biofilm formation and the survival of Salmonella Typhimurium on parsley. Intl J Food Microbiol. 2006;109:229-33.

Leveau JHJ. Microbiology: life on leaves. Nature. 2009;461:741.

Mahbuba A, Islam S, Mazumdar RM, Fakruddin M, Bhuiyan HR, Sarker A. A biological tool to combat against multidrug-resistant Salmonella isolated from poultry of Chittagong City, Bangladesh. Intl J Nat Sci. 2012;2(1):71-5.

Montanari F. Managing Risks in Imports of Non-Animal Origin: The EU System of Reinforced Border Surveillance, Risk Regulation in Non-Animal Food Imports: The European Union Approach, 29-56. Cham: Springer International Publishing; 2015. p. 39. http://dx.doi.org/10.1007/978-3-319-14014-8_2.

Nailya A. Human Pathogens - The Plant And Useful Endophytes. J Med Microbiol \& Diagnosis 2013;2(03).

Nipa MN, Mazumdar RM, Hasan MM, Fakruddin M, Islam S, Bhuiyan HR, lqbal A. Prevalence of Multi drug resistant bacteria on raw salad vegetables sold in major markets of Chittagong city, Bangladesh. Middle-East J Sci Res. 2011;10(1):70-7.

Orue N, Garcia S, Feng P, Heredia N. Decontamination of Salmonella, Shigella and Escherichia coli 0157:H7 from leafy green vegetables using edible plant extracts. J Food Sci. 2013;78(2):M290-6.

Penteado AL, Eblen BS, Miller AJ. Evidence of Salmonella internalization into fresh mangos during simulated post-harvest insect disinfection procedures. J Food Protect. 2004;67(1):181-4.

Reina LD, Fleming HP, Bredit Jr F. Bacterial contamination of cucumber fruit through adhesion. J Food Protect. 2002;65(12):1881-7.

Schikora A, Garcia AV, Hirt H. Plants as alternative hosts for Salmonella. Trends Plant Sci. 2012;17(5):245-9. 
Semenov AM, Kuprianov AA, van Bruggen AH. Transfer of enteric pathogens to successive habitats as part of microbial cycles. Microbial Ecol. 2010;601:239-49.

Singh BR, Singh M, Babu N, Chandra M, Agarwal RK. Prevalence of multidrugresistant Salmonella on ready-to-eat betel leaves (Paan) and in water used for soaking betel leaves in North Indian cities. J Food Protec. 2006;69(2):288-92.

Singla R. Prevalence of high risk bacterial pathogens in Indian fresh vegetables and novel strategies for their inactivation. Diss. Thapar University, Patiala, 2011. Weblink: http://dspace.thapar.edu:8080/jspui/bitstream/10266/1741/3/1741.pdf.

Singla R, Ganguli A, Ghosh M, Sohal S. Evaluation of sanitizing efficacy of acetic acid on Piper betle leaves and its effect on antioxidant properties. Intl J Food Sci Nutr. 2009;99999:1. doi:10.1080/09637480903114110.

Sivapalasingam S, Friedman CR, Cohen L, Tauxe RV. Fresh produce: a growing cause of outbreaks of foodborne illness in the United States, 1973 through 1997. J Food Protect. 2004:67:2342-53.

Solomon EB, Yaron S, Matthews KR. Transmission of Escherichia coli O157:H7 from contaminated manure and irrigation water to lettuce plant tissue and its subsequent internalization. Appl Environ Microbiol. 2002;68(1):397-400.

Sperandio V, Torres AG, Kaper JB. Quorum sensing Escherichia coli regulators B and C (QseBC): A novel two-component regulatory system involved in the regulation of flagella and motility by quorum sensing in Escherichia coli. Mol Microbiol. 2002:43:809-21.

Warriner K, Ibrahim F, Dickinson M, Wright C, Waites WM. Internalization of human pathogens within growing salad vegetables. Biotechnol Genetic Eng Rev. 2003;20:117-34.

Wiedemann A, Virlogeux-Payant I, Chausse A-M, Schikora A, Velge P. Interactions of Salmonella with animals and plants. Front Microbiol. 2015; 5: 792. doi:10.3389/fmicb.2014.00791

Zheng J, Allard S, Reynolds S, Millner P, Arce G, Blodgett RJ, Brown EW. Colonization and Internalization of Salmonella enterica in Tomato Plants. Appl Environ Microbiol. 2013;79(8):2494-502.

Zhuang RY, Beuchat LR, Angulo FJ. Fate of Salmonella Montevideo on and in raw tomatoes as affected by temperature and treatment with chlorine. Appl Environ Microbiol. 1995;61:2127-31.

\section{Submit your manuscript to a SpringerOpen ${ }^{\circ}$ journal and benefit from:}

- Convenient online submission

- Rigorous peer review

- Immediate publication on acceptance

- Open access: articles freely available online

- High visibility within the field

- Retaining the copyright to your article

Submit your next manuscript at $>$ springeropen.com 